Teosofia: Indonesian Journal of Islamic Mysticism, Vol. 9, No. 1, 2020, pp. 1-12

e-ISSN: 2540-8186; p-ISSN: 2302-8017

DOI: $10.21580 /$ tos.v9i1.5367

\title{
THE CONCEPT OF MARTYRDOM IN THE VIEW OF JAMĀ'AH ISLĀMIYAH IN INDONESIA
}

\author{
Muzayyin \\ Institut Agama Islam Nahdlatul Ulama Kebumen \\ muzayyinpsikologi@gmail.com
}

\begin{abstract}
:
Religious radicalization is an irrefutable fact emerging mainly in the last decade. Several mass and suicide bombings (the nightclub Paddy's Pub in Bali, JW Marriot Hotel in Jakarta, Resort Police Mosque in Cirebon, Australian Embassy in Jakarta and several Churches in Indonesia) show this most clearly. The latest bombing in a mass building in Surabaya even had a thorough family as its actors. They and actors of other attacks claim that the bombing is of ways to put the doctrine of jihād fi sabilillah into real life. It is therefore, the research employs a qualitative approach which aims to describe the concept of martyrdom as called amaliyat istisyha diyah upon the perspective of Imam Samudera as one of Jamā'ah Islämiyyah's activist which is allegedly responsible for a number of terror attacks in South East Asia. In addition, this research conclude that Martyrdom has no relation to suicide. Its aims at establishing Kalimātullah and Islam, originating from the purest intention. While suicide is a hopeless deed performed by a person who kills himself for his own selfish reason.
\end{abstract}

Keywords: Radicalization, Suicide Bombing, Martyrdom, Jamā'ah Islāmiyah, Jihād Fĩ Sabìlillah

\section{A. Introduction}

$\mathrm{I}$ $\mathrm{n}$ the last decades, religion-based violence escalates significantly. This is mostly related to religious texts that might be misunderstood as teaching 'violence' and are in fact often interpreted literally. ${ }^{1}$ For instance, Wa qātilu almusyrikin kāffah... (Q

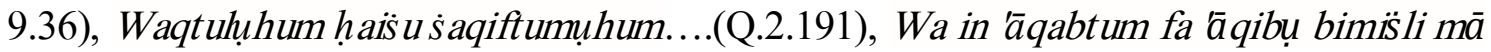
ụqibtum bih....(Q.16.126), and Wa qā tilụhum ḥattā lā takuna fitnatuw....(Q.8.39). Many actors even cite these texts as the basis for their violent acts in the name of religion (Islam) as in different context and, methodologically speaking, interpret them in a literal way. They even claim to have been doing what they call jihäd fí sabïlillah with a specific goal i.e.

1 Abdul Mustaqim, "De-Radicalization in Quranic Exegesis (Re-Interpretation of Violence Verses Toward Peaceful Islam)," in Proceedings of the International Conference on Qur'an and Hadith Studies (ICQHS 2017), vol. 34 (Paris, France: Atlantis Press, 2017), https://doi.org/10.2991/icqhs-17.2018.34. 
fighting those against Islam. ${ }^{2}$ It is as if their religion teaches them to kill others, simply because different religion and ideology. ${ }^{3}$ These bombings and terror attacks, even suicide bombings, are often associated to radical groups of muslim. In Indonesia, Jamaah Islamiyah (JI) is often mentioned in news on such attacks as Bali Bombing on Oct 12, 2002.

Dealing with bombings and terror attacks, Ali Imron in his book "Ali Imron Sang Pengebom", asserted that the main factor of the bombings which is intended for jihād fi sabilillah, exactly wishing to carry out the obligation of jihad immediately. The desire, according to Ali, was motivated by the virtue of jihad in the path of Allah, the high degree of mujahid, the virtue of martyrdom, the high degree of people who died martyrdom, and the victory of mujahid in the path of Allah. Therefore, on that perspective the bombers are engaging the action. They couldn't bear to accomplish and even going out to quick the holy war. They wished to claim to be a hero or as so-called "mujahid", not as someone who is silent (do not want to fight). And they did not want to be a hypocritical because of not accomplishing jihad or even fear of war. ${ }^{4}$

This proves that there is a professional underground group that operates behind the attacks. ${ }^{5}$ Jamaah Islamiyah was established on January 1, 1993 by some Indonesians known to have sort of relation to an allegedly Iraqi terrorist organization Al Qaeda. It's main goal is to establish an Islamic nation in Southeast Asia with terror and 'revolution'. 6 It has a socalled irhābi (terrorism) doctrines that allow the members to conduct war against those they consider as 'enemies of our religion'. They further categorize those enemies into two; far enemy like America and its allies, and near enemy like non-muslims, priest, and nonmuslim Indonesian government. ${ }^{7}$

2 Jihad is often cited as the cause of the emergence of violence in Muslim societies. The understanding needs to be re-examined. Because according to Amin Abdullah normatively, none of the religious teachings that encourage and encourage followers to commit acts of violence against followers of other religions (others) outside the group. However, historically-factually, violence was committed by some community members under the pretext of religion. see Muhammad Amin Abdullah, "Rekonstruksi Metodologi Studi Agama Dalam Masyarakat Multikultural Dan Multirelijius. The Speech of Inauguration of Professor of Philosophy of IAIN Sunan Kalijaga Yogyakarta," The Speech of Inauguration of Professor of Philosophy of IAIN Sunan Kalijaga Yogyakarta § (2000). 1-2.

3 Mustaqim, "De-Radicalization In Quranic Exegesis (Re-Interpretation Of Violence Verses Toward Peaceful Islam).”, 1.

4 Ali Imron, Ali Imron Sang Pengebom: Kesadaran \& Ungkapan Penyesalan (Jakarta: Republika, 2007), 230.

5 Jamaah Islamiyah in fact, has a good system or structure. Some of are responsible for the organizational structure, seeking the funding, recruiting people who will carry out suicide bombing operations, managing leadership issues, working in charge of planning programs, and the last one is on building net-working with, or to have such same ideology as JI. See Ardison Muhammad, Terorisme Ideologi Penebar Ketakutan (Surabaya: Liris, 2010), 30-31.

6 As Nugroho, Misteri Noordin M Top Dan Jaringan Terorisme Di Indonesia (Yogyakarta: Pustaka Timur, 2009), 34

7 To read more details about "far enemy" and "near enemy", please, read Solahudin, NII Sampai JI Salafy Jihadisme Di Indonesia (Jakarta: Komunitas Bambu, 2011), 250 
In many attacks, they often conduct secret recruitment for bomber position that they call 'bride'. Noordin M Top, an important figure of JI, is a professional recruiter. ${ }^{8} \mathrm{He}$ has a capability to brain wash 'new comers' and make them willing to become a bomber. ${ }^{9}$ The brainwash process starts mostly with discussions about Moluccas and Poso. It involves videos about mass killing in those areas. Thus, the conflict serves as the area in which they can not only practice their war skills, but also conduct a holy ritual called jihăd. ${ }^{10}$ They consider the attacks as jihād fí sabïlillah rather than violence or extremism.

In Salafi Jihadi ideology, the bomber will die as syăhid (a person dedicating themselves to religion and dying for it). To some people, this is so enlightening. ${ }^{11}$ In May 2018, suicide bombing in Surabaya was conducted by a family. ${ }^{12}$ This shows that radical ideology can easily influence everyone, regardless of the age and social status. On that basis, this article delves the roots of such argument that legitimates syähid operation by investigating Jamaah Islam and mostly one of its important figure, Imam Samudera. It tries to uncover which acts that belongs to syähid category and further its relation to Islamic law (sharia).

\section{B. Brief History of Jama'ah Islamiyyah}

Jama'ah Islamiyah (JI) is an Islamic group operating in Southeast Asia. This becomes deeply militant mainly after Bali Bombing on October 12, 2002, that killed 202 people, and JW Marriot bombing in Jakarta on August 5, 2003, that killed 12 people. A year later, another bombing in governmental area in Jakarta, i.e. Australian Embassy, on

8 These are several bombardments and did commit suicide bombing such as; the nightclub Paddy's Pub in Bali, October 12, 2002, it took 202 lives were lost and 300 others were injured in the explosion. It's claim as the biggest attack in the history of Indonesia. Subsequently On August 5, 2003, a suicide bombing at the JW Mariott Hotel in Jakarta. On September,9, 2004, a suicide bombing attacking the Australian Embassy in Jakarta. For further Bali's bombing on October 1, 2005, there were three more bombings occurred. One explosion occurred in Kuta and two in Jimbaran. On July 17, 2009, two people did committed suicide bombings at the JW Marriott and Ritz-Carlton hotels in the Mega Kuningan area, South Jakarta. On April 15, 2011, a suicide bombing attacked at the Adz-Dzikro Mosque. On September 25, 2011, they attacked the Bethel Injil Church, Solo, Central Java. On June 3, 2013, a suicide bombing in front of Poso Police Headquarters. On January 14, 2016 around 11:40 WIB, an explosion was heard at Starbucks Cafe, Gedung Cakrawala, Sarinah. On May 24, 2017, a suicide bombing exploded in Kampung Melayu Terminal, East Jakarta. "Rentetan Bom Bunuh Diri Di Indonesia," 2017, https://kumparan.com/utomo-priyambodo/rentetan-bom-bunuh-diri-di-indonesia, Accessed 1 Dec 2019.

9 Ardison Muhammad, Terorisme Ideologi Penebar Ketakutan. 60

10 "Indonesia Backgrounder: How The Jemaah Islamiyah Terrorist Network Operates Crisis Group,", https://www.crisisgroup.org/asia/south-east-asia/indonesia/indonesia-backgrounder-how-jemaahislamiyah-terrorist-network-operates. accessed 11 Dec 2002.

11 Ardison Muhammad, Terorisme Ideologi Penebar Ketakutan. 61

12 Ali Halidin, The Relationship Between Family and Radicalism, The Colourful of Islamic Studies: An Academic Report from Leiden (Yogyakarta: Pustaka Ilmu, 2019), 3

Teosofia: Indonesian Journal of Islamic Mysticism, Vol. 9, No. 1, 2020

http://journal.walisongo.ac.id/index.php/teosofia 
September 9, 2004, and in churches also in Jakarta, puts Jakarta into 'a tunnel of terror'. ${ }^{13}$ In these attacks, JI was suspected to be the men behind. ${ }^{14}$ American Government saw this organization as terrorists; besides, Indonesian government claims them as an "illegal organization." 15 In October 2002, representative of Singapore government in the United Nations (UN), Kishore Mahbubani, officially submit request to the committee of its Security Council to issue a sort of recommendation letter (later issued no. 1267). It recommends Indonesian government to put JI into a list of terrorist organizations related to Al Qaeda. ${ }^{16}$ In order to see this thesis, we need to show a brief history of JI either ideological or strategic aspects.

JI is an Islamic group established on January 1, 1993, in Malaysia by two Indonesian religious teachers, Abdullah Sungkar and Abu Bakar Ba'asyir. ${ }^{17}$ They both are activists in Al-Irsyad and Dewan Dakwah Islamiyah Indonesia (Indonesian Council for Islamic Proselytizing), joining the Council in $1976 .{ }^{18}$ Sungkar's role is highly instrumental in DI and in turn put him in the position of Minister of Foreign Affairs of DI. The main program of DI is foreign diplomation and militarization for the juniors in Afghan. Yet, in 1992, Sungkar got disappointed for his leader, Ajengan Masduki, joined the thariqah (sufist organization) whose teachings deviate those of DI. In 1993, he established Islamic militant movement namely JI. According to Mark Hong, Sungkar and Ba'asyir got close

13 Zulkifli Haji Mohd Yusoff and Fikri Mahmud, "Gerakan Teroris Dalam Masyarakat Islam: Analisis Terhadap Gerakan Jemaah Islamiyah (J),” Jurnal Usuluddin 21 (June 2005): 39-62. 41

14 M. Zaki Mubarak, "DARI NII KE ISIS: Transformasi Ideologi Dan Gerakan Dalam Islam Radikal Di Indonesia Kontemporer," Epistemé: Jurnal Pengembangan Ilmu Keislaman 10, no. 1 (June 2015), https://doi.org/10.21274/epis.2015.10.1.77-98. 78

15 Abdur Rasyid, "Radikalisasi dan Moderasi: Studi Gerakan Islam Mainstrem Jama'ah Islamiyah dan Nahdatul Ulama di Indonesia," Tamaddun: Jurnal Kebudayaan Dan Sastra Islam 18, no. 1 (July 2018): 104-18, https://doi.org/10.19109/tamaddun.v18i1.2321. 110

16 Singapore's Ministry of Foreign Affairs, 'MFA Press Statement on the Request for Addition of Jama'ah Islamiah to List of Terorists Maintained by the UN", October, 23, 2002. quoted from Miftahul Huda, "Fundamentalisme Dan Gerakan Radikal Islam Kontemporer: Kasus Jama'ah Islamiyah Di Indonesia," El-HARAKAH (TERAKREDITASI) 9, no. 3 (December 2008): 271, https://doi.org/10.18860/el.v9i3.4649. 274

17 Solahudin, NII Sampai JI Salafy Jihadisme Di Indonesia. 6

18 The Darul Islam Movement (DI) established in 1947, led by Sekarmadji Maridjan Kartosuwirjo. on January 1948, Kartosuwirjo founded the Indonesian Islamic Army (TII). On August 1949, Kartosuwirjo called on the Indonesian Islamic State (NII) which was later well-known as so called Darul Islam (DI). In the 1950s DI / NII waged a war against the government. Although the DI rebellion was based in West Java, it later spread to Aceh in 1950, led by Tengku Muhammad Daud Beureueh, and to South Sulawesi in 1953, led by Kahar Muzakkar. On the eve of his death in 1962, Kartosuwirjo reportedly appointed Daud Beureueh as the second NII Imam of the Darul Islam leader in East Java, Haji Ismail Pranoto (Hispran), in 1973 or 1974 when he came to Aceh to ask for blessing from Daud Beureueh to revive Darul Islam. As an Imam, Daud Beureueh reportedly that he personally supported Hispran to bring Abu Bakar Ba'asyir and Abdullah Sungkar into Darul Islam in 1976, Even though, he himself had never met them before. See "Indonesia Backgrounder: How The Jemaah Islamiyah Terrorist Network Operates"," ICG Asia Report, no. 43 (2002)."Indonesia Backgrounder: How The Jemaah Islamiyah Terrorist Network Operates"." 9 
relation with Abdul Wahid Kadungga, ${ }^{19}$ who introduce them to Jamaah Islamiyah, a militant muslim movement which is part of Ikhwanul Muslimin (Muslim Brotherhood) and became popular in Egypt's 1970s. ${ }^{20}$ Accordingly, Martin van Bruinessen argues that JI is an ideological hybrid that has strong relation with radical muslim group in Egypt in terms of organization and jihadi mission. ${ }^{21}$

ACG's Asia Report puts that JI has strict hierarchical structure with an amir at the toppest, ${ }^{22}$ and four territorial divisions called mantiqi or region. ${ }^{23}$ Mahfuh bin Haji Halimi argues that JI is more established than DI, though both of them have still the same goal, i.e. to establish islamic nation in indonesia through weapon fight called jihad. ${ }^{24}$

19 Abdul Wahid Kadungga was a son-in-law to Kahar Muzakkar, the leader of DI in South Sulawesi. In 1971, he went to Europe and became a student in Cologne, Germany. He then joined the PPME (Muslim Youth Association of Europe). In this union, he became acquainted with youth activists from the Middle East, and even became more radical. Important to note that Kadungga is an international Islamic activist. According to Suara Hidayatullah, sometimes Kadungga was in the Netherlands, sometimes he talked with PAS leaders in Kelantan or Terengganu, and he ever met with Osama bin Laden in deepening Afghanistan. "Abdul Wahid Kadungga: Aktivis Internasional," Suara Hidayatullah, October 2000 Suara Hidayatullah, October 2000 http:// www.hidayatullah.com/2000/10/siapa.shtml; see also ICG Indonesia Briefing, 8 Aug 2002, 16

20 Mark Hong, "Jemaah Islamiyah: The Threat and Responses" (Singapore, 2003). 3. quoted from Yusoff and Mahmud, "Gerakan Teroris Dalam Masyarakat Islam: Analisis Terhadap Gerakan Jemaah Islamiyah (JI)." 44; In the early 1970s, Egyptian Jama'ah Islamiyyah (JI) was very close to the government. The new President Anwar Sadat only came to power in releasing imprisoned Ikhwan al-Muslimin figures and using Islamic groups to oppose strong groups who adopted the ideology of Marxism which was previously supported by President Gamal Abdul Nasser. However, unlike the government of his country, JI aims to establish an Islamic State. Since the 1970s, Abdullah Sungkar was get ready to establish a new organization that can work more effectively to reach an Islamic state, later on so-called Jamaah Islamiyah (JI). There were similarities between JI Egypt and JI belong to Sungkar - Ba'asyir. The elements of similarity are recruitment, education, obedience, and jihad. See ICG Asia Report, no.43, 11 Dec 2002.,5

21 Van Bruinessen and Martin, "Geneaologies of Islamic Radicalism in Post Suharto Indonesia" (ISIM and Utrecht University, 2002), http://www.let.uu.nl/-martinvanbruinessen/personal. accessed 24 Apr 2005.

22 "Jemaah Islamiyah in South East Asia: Damaged but Still Dangerous," ICG Asia Report, no. 63 (2003); the highest structure in JI is led by an Amir. Belong to this structure, there are four councils, First, the governing council (qiyadah assembly), Second, the religious council (syuro council), Third, the fatwa council, Fourth, the disciplinary council (hisbah assembly), all appointed by the Amir and subject to his orders. The governing council is led by a central order (qiyadah markaziyah) which in turn gives authority to the four mantiqis leaders and wakalah heads. "Jemaah Islamiyah in South East Asia: Damaged but Still Dangerous." ICG Asia Report No63, 26 Aug 2003, 11

23 JI distributed Southeast Asia into four mantiqi. First, Mantiqi I, covering Peninsular Malaysia and Singapore, was led by Hambali, then after he was captured led by Muchlas (Ali Ghufron). This Mantiqi has a role in providing economic needs for JI operations; Second, Mantiqi II, covers most of Indonesia. This Mantiqi is a target of jihad, led by Abdullah Anshori (aka Abu Fatih); Third, Mantiqi III, covering Mindanao, Sabah and Sulawesi, has a role in carrying out military training, led by Mustopa; Fourth, Mantiqi IV, covering the regions of Papua and Australia, played a role in raising funds, led by Abdul Rahim. "Jemaah Islamiyah in South East Asia: Damaged but Still Dangerous." ICG Asia Report N63, 26 Aug 2003, 11

24 Mahfuh Bin Haji Halimi, “Al-Jama'ah Al-Islamiyyah’s (J) Ideology: Applying Strategy Thoughts in Countering The Ushul Manhaj Al-Harakiy Li Iqomatid Dien,” n.d. accessed 12 Jun 2007, 9.

Teosofia: Indonesian Journal of Islamic Mysticism, Vol. 9, No. 1, 2020

http://journal.walisongo.ac.id/index.php/teosofia 
Since the beginning, the references mainly discussed are highly radical in nature, including al-Thāriq ilā Jamā'atil Muslimịn (towards Jami'atul Muslimin) by Hussain bin Muhammad bin Ali Jabri, Al-Manhaj Al-Haraki Li Sirah An-Nabawiyah (Manhaj Haraki or movement method of the history of the prophet) by Syaikh Munir Muhammad Al Ghadhban, and, Mitsāq Amal Al-Islamī (guides for islamic ritual) by Najih Ibrahlm, Ashlm Abdul Majid, Ishamudin Darbalah. The first two are complementary for the latest. ${ }^{25}$

\section{From Ideologi To Strategy}

The goal of JI is to establish Islamic sharia through jihad fi sabilillah. The organization has the same ideology and doctrines as the salafi jihadi of Egypt. One of them is the jihad doctrine. They consider jihad as the obligation for everybody (fardu ain). ${ }^{26}$ It is due to the fact that Islamic nations are now occupied by non-muslims, including the government. The second doctrine is what so-called tauhid hakimiyah. This doctrine teaches them to believe that political power belongs totally to Allah. This understanding is not in the same line with democracy that give the power to the people. The argument against Islamic shariat is considered against Allah. Accordingly, the holder of the argument becomes infidel, even he/she has pronounced shahada and prayed. They also had irhäbiya (terrorism) doctrine that allows the member to kill civil society once the latter help the nonmuslims to have war against muslim. ${ }^{27}$

Sidney Jones argues that there are four sources for JI. First, salafi ideology that has it's root in Islamic sharia in its purest form, as practiced by the Prophet, companions, and the first generations of muslim. Second, DDII, established 1967 by M Natsir and his allies. Third, Ikhwanul Muslimin of Egypt. Fourth, the Mujahidin ideology of Afghan and Al Qaeda, particularly Abdullah Azzam. Azzam also leads Maktab al-Khidmat and recruits, funds, and trains volunteer coming from muslim countries to make war against Uni Soviet in Afghan. His writings about jihad are translated into Bahasa by Al Alaq publisher, that has relation with JI or Pondok Ngruki in Solo. Mukhlas (Ali Gufran) admits that he is influenced mostly by Azzam. ${ }^{28}$

25 Solahudin, NII Sampai JI Salafy Jihadisme Di Indonesia. 233

26 Salafi groups have the concept of $i^{\prime} d a d$ before jihad. Both are integrated. The concept of $i^{\prime} d a d$ is synonymous with semi-military sports. For more details on this discussion please see Mohamad Sobirin, "Reviving Prophet's Sport Tradition In Modern Day Indonesia: Does Qfollow The Prophet Mean Radical?," in Proceedings of the International Conference on Qur'an and Hadith Studies (ICQHS 2017) (Paris, France: ATLANTIS PRESS: Advances in Social Science, Education and Humanities Research (ASSEHR), 2018), 224-28, https://doi.org/10.2991/icqhs-17.2018.35.

27 Solahudin, NII Sampai JI Salafy Jihadisme Di Indonesia. 7-8

28 Sidney Jones, “Jemaah Islamiyah: A Short Description,” Cultural Journal VII, no. 1 (2003). 
JI's strategy to reach its goal of establishing Islamic nation is imān, hijrah, and jihād. ${ }^{29}$ They are mostly inspired by Ikhwan al-Muslimin, and say that Islamic nation will not be established without Islamization of the individuals (Islamization from below. Thus, the steps to conduct are: first, preach to muslim individuals, conducted in mass capacity in mosques. Second, gather them into 'usrah (literally family). In this circle they got the 'education'. The usrah agenda is conducted in members' house exclusively. Third, the 'usra members would be athered in a bigger circle called Jamā'ah Islāmiyah. It eventually ends up with an Islamic nation. This strategy is first practiced by Ikhwanul Muslimin and then adopted by muslim groups in campus. ${ }^{30}$

JI recruits its members by, first, do mass preaching's in mosques and pesantren. Second, those they think would be interested to their agenda are targeted. They pick them up to join the halaqa, small exclusive circle in which they study Islam (usra). In this halaqa, they are guided by a murabbi (instructor), who will lead them through for steps tabligh (preach), ta'lim (study), tarbiya (mental and physical education), and tamhis (elimination). In the latest step, the members would be selected on the basis of their skills and comprehension, later to be certified as a loyal member. ${ }^{31}$

\section{Jamaah Islamiyah and Interpretation of the Martyrdom Concept}

Many have argued that Jamā'ah Islāmiyah (JI) is the one responsible for bombing attacks in several places in the early 2000s. They are firstly traced after the Bali bombing on October 12, 2002, particularly after the key actors got arrested in Paddy's Pub and Sary Club in Legian, Kuta, Bali. One of the key actors is Imam Samudera, an activist of JI and loyal follower of Salafi Jihadi ideology. ${ }^{32} \mathrm{He}$ is coordinator of the bombing attack and the well trained actor in recruiting the bombing. ${ }^{33}$ In case of Bali bombing on October 12, 2002, Ali Imron reveals that there are two bombing attack that they call istisyhadah (the way to be shahid), they are Iqbal alias Isa and Jimmi alias Arnasan. ${ }^{34}$

Samudera is as well trained as Noordin M Top, one of the key figures in Malaysia. $\mathrm{He}$ is well trained in brainwashing the new members. More often than not, the brainwashing process is began by the discussion about Moluccas and Poso. It involves videos about mass killing in those areas. People are then willing to do suicide bombing.

\footnotetext{
29 Yusoff and Mahmud, "Gerakan Teroris Dalam Masyarakat Islam: Analisis Terhadap Gerakan Jemaah Islamiyah (JI)." 50

30 Yusoff and Mahmud. 51

31 "Indonesia Backgrounder: Jihad in Central Sulawesi"," ICG Asia Report, no. 74 (2004). 18; see also Solahudin, NII Sampai JI Salafy Jihadisme Di Indonesia. 240

32 “Indonesia Backgrounder: Jihad in Central Sulawesi"." ICG Asia Report, no.74.,1

33 Please, read more Imron, Ali Imron Sang Pengebom:Kesadaran \& Ungkapan Penyesalan.

34 Imron. 108
}

Teosofia: Indonesian Journal of Islamic Mysticism, Vol. 9, No. 1, 2020 
Basically Samudera and Noordin M Top convince the suicide bombing actors by promising them heaven and angels. Although, Not all the JI members can do that.

Samudera might says that jihad as the obligation for every individuals to against disbelievers (Musyrikin). Therefore, the law of jihad which was originally fardhu kifayah then it might turned to be fardhu 'ain (an obligation for all Muslim). He cites Osama bin Laden saying that once a metre of Muslim's land is occupied by disbelievers, every muslim is obliged to take it back free. In today's context, Samudera sees that the colonials have murdered billions of muslim from Iraq, Afghan, Somalia, and Indonesia. Muslim thus are obliged to do jihad against them. ${ }^{35}$ In many cases, It might say that the idea of attack of Osama bin Laden toward Musyrikin is more or less influences Samudera, particularly in formulating the concept of his jihad to attack or make war against Musyrikin wherever, whenever they are and no matter how old and young they are.

Samudera interprets jihad as revenge. This is, to him, due to the fact that nonmuslims had been threatening and murdering muslims. Thus, muslims must do something to make this stop. This interpretation is most seen in jihad definition that he states, i.e. make war against non muslims who attack muslims and islamic countries. The sharia-based jihad is what he calls jihäd fi sabilillah. ${ }^{36}$ To him, the intention of Bali bombing proves that the attack is jihäd fi sabilillah, for it targets colonials, namely Americans and their allies. The mass assassination in Afghan (2001) is another witness. The colonials kill poor people and the babies. ${ }^{37} \mathrm{He}$ bases his argument on Quranic verse, “... and fight against the disbelievers collectively as they fight against you collectively. And know that Allah is with the righteous (who rear Him)." (Q 9: 36)

As the one responsible for Bali bombing, Samudera states that the action is istishhadah. In this context, the motive is the same as in Kenya and Tanzania, 'And (Yemen), WTC and others, namely as the fight against disbelievers and belong to jiha $d$ fi sabilillah. ${ }^{38}$ To Samudera, it is totally different from suicide bombing. Istishhad aims at establishing kalimatullah, fight for islam, with a pure intention. Thus, the actors would become shahid. The ulama, like Osama bin Laden, Aiman Azh-Zhawahiri, Muhammad Athef, Sulaiman Abu Ghaits, ${ }^{39}$ accordingly, issue a fatwa that allows such attack. The istishhad ends up with heaven. Suicide bombing, on the other side, has no relation to

35 Imam Samudra, Aku Melawan Teroris, (Solo: Jazera, 2004). 97

36 Samudra. 108

37 Samudra. 109

38 Samudra. 188

39 Ahluts Tsughur are people who stand guard or are on the fronts of jihad, i.e. people who are closer to Allah. Every time they are faced with enemy threats. At times the enemy can kill them, and vice versa. Death feels so close with them. Therefore, the heart will become cleaner. Only thought of killing or being killed. In case, Imam Samudra argued that Allah guarantees that they will truly be guided by Allah SWT. Samudra. 172 
kalimatullah. Suicide ends up with hell. ${ }^{40}$ The basis for such argument is a hadith: "of people before you, there is someone got hurt, he then took a knife and put it into his hand and eventually dies. Allah said, my servant do it before me mine. I will not let him jannah." (Shahih Bukhari-Muslim from Jundab bin Abdullah al-Bajili).

Dealing with various kinds of fatwas of the Bombing to seek syahid, Samudra said the mujāhidin certainly seem were not confused about choosing which opinion was closer to the truth, more important, and even the best to be followed. The problem of martyrdom bombing/operation was not a strange thing and it was not new anymore, Samudra stated. And he further said that as stated by Sufyan bin Uyainah ra, a Tabi'in Ulama and including a profess or of Imam Shafi'i, that was, you should follow the (opinion) mujāhidin and experts-tsughur, because they always shaded by hidayat. In addition, mujāhidin had an important key in responding to various fatwas that seem confusing. To strengthening that Samudra addressing to the word of God, "And those who strive in our way, we will truly show them our ways, and indeed, Allah is truly with those who do good." (QS.Al Ankabut:69).

Samudera then explains the media for istishhäd. In the process either with or without bomb, istishhād has different background and motivation. It has no relation to suicide. To him, the question is not whether the actor dies or does not. It is the intention. Basically, the morality aspect is the first standard. If the intention is to take down the enemy, and control the jihad motivation of the muslim, then it is so encouraged. However, Samudera says that before the operation, the actor must have strong assumption that he will die of the attack. ${ }^{41}$

There are two basis for Samudera argument. First, Imam Ibnu Nuhas AsySyafi'iyah's argument that cites Imam Abu Hamid al-Ghazali, who says, "there are no dissenting opinion whether a muslim may or may not attack a barricade of disbelievers and fight them, even though he knows he will get killed." Second, Muhammad b. al-Hasan, who says "if a Muslim fight against a thousand of disbelievers, and he is alone, then the attack is allowed as long as he believes that he will make it, or at least make the enemy down a step. Otherwise, the attack is makrüh, better not to do. If he tries to trigger muslims' bravery to fight against disbelievers, then it is allowed. Same thing if he aims to put terror against the enemy, to let the enemy know that muslim is strong." 42

On the basis of the argument, he asserts that anyone who dies for Allah's religion and taking down the disbelievers, he/she has got an achievement. He is at the top of the hierarchy. Samudera even claims that Allah praises the attack, for He says, "Indeed, Allah has purchased from the believers their lives and their properties (in exchange) for that they

\footnotetext{
40 Samudra. 183-4

41 Samudra. 182

42 Samudra. 182
}

Teosofia: Indonesian Journal of Islamic Mysticism, Vol. 9, No. 1, 2020 
will have paradise." (9: 111) It is noteworthy that istishhäd idea of Samudera is inspired by the success of the previous istishhäd in another country such as Palestine. It is to him an effective way to fight against Jews. He also mentions a global istishhād by Al Qaeda. For instance, the operation occurs in October 2000 to the US' destroyer Cole, kills 17 people and hurts 42 people, and another successful istishhäd was on September 11, 2001 in WTC building in New York, that killed 6000 people. ${ }^{43}$

Dealing with martyrdom method which officially used as strategy against the enemy, Abu Muhammad Al-Maqdisi, one of the most influential contemporary jihadi ideologists, stated that many of young people imitated the success of the martyrdom as did the mujahidin in Chechnya. It is however, they practice it without experience and expertise so they easily reap a failure. In his views, as long as the enemy could still be paralyzed by traditional method without blasting in such way, therefore it can still be criticized. He rebuked and criticized the young men to be aware of, inviting them to always guard Allah, the Muslims, Jihad, etc. Through his book, "Mereka Mujahid Tapi Salah Langkah", AlMaqdisi officially admitted that he used to write about amaliyah istisyhädiyah and putted it into the doctrine as well as carried out by some mujahidin by sneaking in among the infidels and blown themselves up to paralyzed the disbelievers. However, he insisted that the method has certain limitations and he does not make it as a strategy of war which is absolutely right in accordance with Islamic values. ${ }^{44}$

\section{E. Conclusion}

Jamā'ah Islāmiyah (JI) is the one responsible for bombing attacks in several places in the early 2000s. One of the key actors is Imam Samudera, an activist of JI and loyal follower of Salafi Jihadi ideology which is allegedly responsible for the attack so called martyrdom or istishhād (a way to become shahid). According to Samudera, Martyrdom has no relation with suicide or it is not part of suicide. Martyrdom aims at establishing kalimatullah and Islam, originating from the purest intention. In the process either with or without bomb, istishhād has different background and motivation. In his views, the question is not whether the actor dies or does not. It is the intention. Basically, the morality aspect is the first standard. If the intention is to take down the enemy, and control the jihad motivation of the muslim, then it is so encouraged. However, Samudera says that before the operation, the actor must have strong assumption that he will die of the attack. It is therefore, he strengthened that martyrdom is allowed by the ulama Ahlus $\dot{S}$ ughur to do such attack and they will get paradise in exchange, while suicide bombers will get hell, for they have no relation to Islam establishment.

43 Samudra. 186

44 Abu Muhammad Al-Maqdisi, Mereka Mujahid Tapi Salah Langkah, Translate: Abu Sulaiman (Solo: Jazera, 2007). 11 


\section{Bibliography}

Suara Hidayatullah. “Abdul Wahid Kadungga: Aktivis Internasional,” n.d.

Abdullah, Muhammad Amin. Rekonstruksi Metodologi Studi Agama dalam Masyarakat Multikultural dan Multirelijius. The Speech of Inauguration of Professor of Philosophy of IAIN Sunan Kalijaga Yogyakarta, The Speech of Inauguration of Professor of Philosophy of IAIN Sunan Kalijaga Yogyakarta $\S$ (2000).

Al-Maqdisi, Abu Muhammad. Mereka Mujahid Tapi Salah Langkah, Translate: Abu Sulaiman. Solo: Jazera, n.d.

As Nugroho. Misteri Noordin $M$ Top Dan Jaringan Terorisme Di Indonesia. Yogyakarta: Pustaka Timur, 2009.

Bruinessen, Van, and Martin. "Geneaologies of Islamic Radicalism in Post Suharto Indonesia.” ISIM dan Utrecht University, 2005.

Halidin, Ali. The Relationship Between Family and Radicalism, The Colourful of Islamic Studies: An Academic Report from Leiden. Yogyakarta: Pustaka Ilmu, 2019.

Halimi, Mahfuh Bin Haji. “Al-Jama'ah Al-Islamiyyah's (JI) Ideology: Applying Strategy Thoughts in Countering The Ushul Manhaj Al-Harakiy Li Iqomatid Dien," n.d.

Hong, Mark. “Jemaah Islamiyah: The Threat and Responses.” Singapore, 2003.

Huda, Miftahul. "Fundamentalisme Dan Gerakan Radikal Islam Kontemporer: Kasus Jama'ah Islamiyah Di Indonesia." El-HARAKAH (TERAKREDITASI) 9, no. 3 (December 2008): 271. https://doi.org/10.18860/el.v9i3.4649.

Imron, Ali. Ali Imron Sang Pengebom:Kesadaran \& Ungkapan Penyesalan. Jakarta: Republika, 2007.

"Indonesia Backgrounder: How The Jemaah Islamiyah Terrorist Network Operates"." ICG Asia Report, no. 43 (n.d.).

"Indonesia Backgrounder: How The Jemaah Islamiyah Terrorist Network Operates Crisis Group," n.d.

"Indonesia Backgrounder: Jihad in Central Sulawesi"." ICG Asia Report, no. 74 (n.d.).

"Jemaah Islamiyah in South East Asia: Damaged but Still Dangerous." ICG Asia Report, no. 63 (2003). 
Jones, Sidney. "Jemaah Islamiyah: A Short Description." Cultural Journal VII, no. 1 (2003).

Mubarak, M. Zaki. "DARI NII KE ISIS: Transformasi Ideologi Dan Gerakan Dalam Islam Radikal Di Indonesia Kontemporer." Epistemé: Jurnal Pengembangan Ilmu Keislaman 10, no. 1 (June 2015). https://doi.org/10.21274/epis.2015.10.1.77-98.

Muhammad, Ardison. Terorisme Ideologi Penebar Ketakutan. Surabaya: Liris, 2010.

Mustaqim, Abdul. "DE-RADICALIZATION IN QURANIC EXEGESIS (REINTERPRETATION OF VIOLENCE VERSES TOWARD PEACEFUL ISLAM)." In Proceedings of the International Conference on Qur'an and Hadith Studies (ICQHS 2017), Vol. 34. Paris, France: Atlantis Press, 2017. https://doi.org/10.2991/icqhs-17.2018.34.

Rasyid, Abdur. "Radikalisasi Dan Moderasi: Studi Gerakan Islam Mainstrem Jama'ah Islamiyah Dan Nahdatul Ulama Di Indonesia." Tamaddun: Jurnal Kebudayaan Dan Sastra Islam 18, no. 1 (July 2018): 104-18. https://doi.org/10.19109/tamaddun.v18i1.2321.

“Rentetan Bom Bunuh Diri Di Indonesia,” 2017.

Samudra, Imam. Aku Melawan Teroris Solo. Jazera, 2004.

Sobirin, Mohamad. "Reviving Prophet's Sport Tradition In Modern Day Indonesia: Does Follow The Prophet Mean Radical?" In Proceedings of the International Conference on Qur'an and Hadith Studies (ICQHS 2017), 224-28. Paris, France: ATLANTIS PRESS: Advances in Social Science, Education and Humanities Research (ASSEHR), 2018. https://doi.org/10.2991/icqhs17.2018.35.

Solahudin. NII Sampai JI Salafy Jihadisme Di Indonesia. Jakarta: Komunitas Bambu, 2011.

Yusoff, Zulkifli Haji Mohd, and Fikri Mahmud. "Gerakan Teroris Dalam Masyarakat Islam: Analisis Terhadap Gerakan Jemaah Islamiyah (JI).” Jurnal Usuluddin 21 (June 2005): 39-62. 